\title{
EXPLAINING THE RISING PRECARIAT IN SPAIN
}

\author{
Elena DE LA POZA (D) ${ }^{*}$, Lucas JODAR ${ }^{(12}$, Paloma MERELLO ${ }^{(D)}$, \\ Adrián TODOLI-SIGNES (DD 4 \\ ${ }^{1}$ Center of Economic Engineering, Universitat Politècnica de València, 46022, Valencia, Spain \\ ${ }^{2}$ Instituto de Matemática Multidisciplinar, Universitat Politècnica de València, 46022, Valencia, Spain \\ ${ }^{3}$ Department of Accounting, University of Valencia, 46071, Valencia, Spain \\ ${ }^{4}$ Department of Labour and Social Security Law, Faculty of Law, University of Valencia, \\ 46020 Valencia, Spain
}

Received 31 March 2019; accepted 01 September 2019

\begin{abstract}
Spanish GDP indicator figures recover while the risk of poverty has not stopped increasing since 2007 given the continuous austerity policies adopted by Governments, while labour and welfare conditions have worsened. A new phenomenon is emerging: the flattening of the Spanish middle class.

This study proposes a model to quantify the number of individuals according to their level of precariousness in Spain. The model allows us to predict the behaviour of society in Spain given the mimetic nature of humans by constructing a discrete finite epidemiological model that classifies and quantifies the population in Spain according to its risk of precariousness. Our results show a rise in the precariat of $3 \%$ (representing $39 \%$ of the total population at the end of the study).

The relevance of this study lies in providing measures to governments that can mitigate the negative effects of this problem and stop its growth. Indeed tax measures to help firms to distribute their profits among employees and measures engaging a labour reform to establish limits to the rate of temporary jobs and working overtime should be considered.
\end{abstract}

Keywords: economy, technology, labour, modelling, precariat, risk, society, Spain, wages.

JEL Classification: C63, C81, E24, I30, O33.

\section{Introduction}

In 2017, the decline in Spanish unemployment figures announced the end of the crisis. Yet despite positive Spanish GDP indicator figures, the risk of poverty has not stopped increasing since 2007 given the continuous austerity policies adopted by Governments, while labour and welfare conditions have worsened (Clarke \& Newman, 2012).

\footnotetext{
${ }^{\star}$ Corresponding author. E-mail: elpopla@esp.upv.es
}

\section{(C) 2020 The Author(s). Published by VGTU Press}

This is an Open Access article distributed under the terms of the Creative Commons Attribution License (http://creativecommons. org/licenses/by/4.0/), which permits unrestricted use, distribution, and reproduction in any medium, provided the original author and source are credited. 
Thus a new phenomenon is emerging: the flattening of the Spanish middle class, caused partially by the so-called "gig" or "platform" economy characterised as a race to the bottom for wages and labour rights, which leads to workers' impoverishment and new forms of spurious self-employment (Barbieri, 2009; Muñoz de Bustillo Llorente \& Pinto Hernández, 2016; Todolí Signes, 2015, 2017a).

The creation of new contracts produced by economic recovery not only lack proper economic conditions, but also suitable conditions. As a result, new contracts are mainly temporary/involuntary part-time or false self-employed rather than permanent (Drahokoupil \& Fabo, 2016; Muñoz de Bustillo Llorente \& Pinto Hernández, 2016; Rubery, Grimshaw, Keizer, \& Johnson, 2018). This effect is more dramatic for disabled people as employment brings not only the necessary income to lead a reasonable lifestyle, but also acts as an important part of social inclusion (Čábelková, 2015).

In general, the precariat abruptly emerges in western countries (Standing, 2012). The importance of this problem is evident and is currently in force; the crisis has led to the Spanish middle class being destroyed due to the increasing divergence of salaries, traditionally fixed in Spain, and the consequent imbalance in society's welfare, accelerated by the automation process and the emergence of the digital economy (Micklethwait \& Wooldridge, 2014; Srnicek, 2017).

The labour market is doubly affected by technological innovation. On the one hand, the destruction of jobs occurs if they involve repetitive tasks, which are replaced with the automation process (Arntz, Gregory, \& Zierahn, 2016); on the other hand, production costs lower because many activities are digitised and geographically transferred to labour markets with lower costs that do not require physical movements (Rodríguez-Piñero \& Hernández-Bejarano, 2017).

In addition, digitisation requires qualified people who have invested in their education and are trained to adapt to a constantly changing environment (Spitz-Oener, 2006).

Hence polarisation in the distribution of new wages occurs (Goos, Manning, \& Salomons, 2014) as job creation occurs at both ends of the wage distribution; that is, jobs that require minimum and maximum qualification levels, which leads to minimum and maximum wages, compared to those found in the central part of distribution (Krusell, Ohanian, Rios-Rull, \& Violante, 2000; Hornstein, Krusell, \& Violante, 2005; Acemoglu \& Autor, 2011).

Complex knowledge and technology types are becoming predatory formations that go beyond a project of a firm, an individual or a government (Sassen, 2014).

Although the consequences of digitalisation and automation in the Spanish labour market are a fact (Hawksworth, Berriman, \& Goel, 2018), the growth of the Precariat cannot be attributed solely to this variable because other factors trigger the socio-economic inequality experienced by the population in Spain (Martínez García, 2013; Pratt, 2015).

The relevance of this problem drives to loss of citizenship's quality of life and to inequality growing in the population that acts as a catalyser to deteriorate individuals' health (Wilkinson, 2005; Bentley, Baker, \& Aitken, 2019), which means they are increasingly discontent with the political class, perceived as being privileged and incapable of solving the working class' problems. Thus electoral repercussions result at both levels: national and European 
(Rubery et al., 2018). The rise in a precarious population promotes populist political parties emerging, which demand defending citizens' rights and cause political and economic instability (Doogan, 2009; Galston, 2018; De la Poza, Jódar, \& Pricop, 2017).

This study proposes a model to quantify the number of individuals according to their level of precariousness in Spain. Thus following Fischhoff and Kadvany (2011), it is necessary to measure the unknown in order to control it and to later improve it. The presented sociological problem uses the quantification issues suggested by Charlwood et al. (2014) throughout a recently emerged population model (Goldthorpe, 2016).

Individual behaviour is unpredictable, but the aggregate one can be predicted by mimetic contagious and herding human behaviour (Christakis \& Fowler, 2009; Girard, 2008; Raafat, Chater, \& Frith, 2009). According to Damasio (2018), humans are driven by emotions.

Our model allows us to predict the behaviour of society in Spain given the mimetic nature of humans by constructing a discrete finite epidemiological model (Haddad, Chellaboina, \& Nersesov, 2002) that classifies and quantifies the population in Spain according to its risk of precariousness. Despite previous approaches focusing on both building indicators based on surveys to make comparisons from different perspectives (employees' well-being and health) (Bericat \& Cascales-Mira, 2019; Symeonaki, Parsanoglou, \& Stamatopoulou, 2019) and the quality of employment in Europe, they did not quantify the number of individuals or their level of precariousness in a given geographical area.

Thus we identify the factors that define individuals' behaviour and therefore, explain their transit to other categories. The identified factors are quantified based on sociological, demographic and economic variables on a short-term horizon from 2017 to 2021 (De la Poza \& Jódar, 2018). Unlike previous studies that centred on precarious employment (Brady \& Biegert, 2017; Kiersztyn, 2017), we managed a precariat concept that was not only limited to individuals in the labour market, but also embraced the retired population.

Thus, we quantified at each given time the number of individuals by their precariousness risk. To our knowledge, this is the first study to dynamically score precariousness by levels and sizes in a given country.

Having quantified the problem, the model allows the implementation of labour-economic-fiscal measures to be simulated to quantify and better understand their impact on the Spanish citizenship.

The relevance of this study lies in providing measures to Governments that can mitigate the negative effects of this problem and stop it growing (Rifkin, 2011). Measures to raise employees' wages by distributing corporate profits and offering incentives to the companies that do this (tax cuts) and by simulating the implementation of the labour reform to reduce the precariat (converting seasonal and part-time contracts into permanent ones).

The paper is organised as follows: the next section introduces the population at risk of precariousness concept and previous research. Then come the hypotheses, the definition of parameters, and the quantification of transit coefficients. Afterwards, the building of the model is presented. Later the results of the model and its simulations are shown with a variety of sensitive parameters. Finally, the study conclusions are presented. 


\section{Understanding the magnitude of precariousness in Spain}

Spanish macro-economic recovery, quantified through the decline in unemployment rates (26.9\% in 2013 and $15.8 \%$ in the second quarter of 2018), is not perceived by citizens as indicators reveal, such as the poverty rate estimated at $22.3 \%$ in 2018 or the involuntary temporary employment rate of $91 \%$ (Eurostat, 2018). At the start of the crisis, and due to the austerity measures adopted by governments to contain budget deficits, the Spanish middle class reduced, which gave rise to greater social and gender inequality in the modern history in Spain, promoted by wage devaluation and the accelerated growth of both divergence of income (20-fold more than the European average) and inequality (Oxfam Intermón, 2018; Costas, 2018).

The precarious population comprises individuals whose wages are below 1.250 euros/ month to live autonomously and in dignified living conditions (Nachtwey, 2017).

These people suffer unstable employment because they have temporary, flexible or partial contracts (the rate of temporary contracts for women is $25.2 \%$ compared to $7.9 \%$ for men; Spanish National Statistics Institute or INE, 2015), but also false self-employed workers and workers with permanent jobs whose wages do not correspond to the cost of living (lower than 1. 250 euros; INE, 2016).

Precariousness also affects retired citizens. That is, those whose contributions are minimal or nonexistent, and those whose pensions do not allow them to live with dignity (pay the basic expenses deriving from renting or mortgage, electricity, water and gas, food, or unexpected expenses like buying a washing machine or heater) (Andrés, 2018)

The precarious population also includes those youths who adhere to the labour market (for the first time in the history of Spain, workers are more qualified than the jobs on the labour market). At the same time, neither the tax payments made to the Social Security System (SSS) nor the working population with the capacity to pay to the SSS grow to the same extent as social needs because the fertility index shows a decreasing trend (INE, 2018).

The relevance of the problem is such that approaches have already been made by constructing and analysing indicators, such as the Living Conditions Survey of the Spanish population in 2017, published by INE 1 year later in June 2018, with figures of the Spanish population at risk of poverty (using the income data per household in 2016), which came to $22.2 \%$. Eurostat (2016) has constructed an indicator to measure the "population rate at risk of poverty" using the median income for 2016 to determine the threshold (last published information), which came to $27.9 \%$ for the population in Spain. This figure is above the European average of $23.5 \%$. Felgueroso, Millán, and Torres (2018) built an indicator for the population that is especially vulnerable to employment in Spain using the statutory minimum wage as a threshold. However, highlighting the main characteristics of poverty is important for creating social policies, and this helps marginalised groups and supports inclusive growth at the same time. Poverty and social exclusion are the main barriers that restrain inclusive growth, which is one of three main priorities in the EU (Dudek \& Lisicka, 2013; Pęciak \& Tusińska, 2015; Kalinowski \& Kiełbasa, 2017).

Although the aforementioned indicators are helpful, the problem is not entirely addressed due to the conceptualisation and methodology used in the cited studies; information from surveys and statistical inference, which offers only a partial and fixed image of the Spanish 
social reality, and always obsolete estimates similarly to photographs. What is even worse, however, is that they do identify neither the aggravating factors of the situation nor the potential solutions to it. Unlike the proposed model identifying the factors, it allows simulations of scenarios and their dynamic prediction. The short-term period also allowed the assumption that the parameters were not excessively volatile for the considered study period.

\section{Model construction}

Dealing with problems that involve human behaviour is a complex task because of mimetic human behaviour (Girard, 2008), the influence of emotions in the decision-making process (Damasio, 2018), the contagion effect (Christakis \& Fowler, 2009) and the human herding effect (Raafat et al., 2009). Thus human behaviour has an important irrational component that derives from its emotionality and which varies over time. Apart from the external uncertainties that derive from economy, political stability or the culture, uncertainty arises when modelling and simulating processes that engage human behaviour that has been disrupted by previous effects (emotions).

Unlike previous methodological approaches that have neglected the existence of uncertainty in modelling and analysing data sets by statistical techniques, in recent decades methodologies have evolved to include uncertainty, but to also differentiate between static and dynamic models, such as Monte Carlo or fuzzy techniques (León-Castro, Merigó, AvilésOchoa, Gil-Lafuente, \& Herrera-Viedma, 2019).

This paper proposes a compartmental population model where the target population is split into subpopulations according to its level of precariousness risk. The advantage of our model is that as it is dynamic, it allows the value of each subpopulation to be quantified at a given time period. The only necessary empirical data set is the population at the beginning of the study period. Thus the quantification of the coefficients considered to confer transits a size are calibrated by allowing a discrete mathematical model to be constructed and formulated in terms of an explicit system of difference equations. Thus by starting from the initial ones, subpopulations are computed dynamically during the study period.

Our modelling approach was based on the dynamic changes of the population at risk of precarity over a predetermined finite time period (2017-2021). So a model described by an explicit system of difference equations was built. Each equation enables us to quantify the number of individuals in each category at a given time (n). For this purpose, the target population of our study included Spanish residents aged over 18 years. The study period started in December 2017 and ended in December 2021. It began by splitting the target population into six mutually exclusive categories according to individuals' degree of precarity in a given semester (n). However, individuals' behaviour was dynamic and influenced by environmental factors, such as economic, legal-occupational, technological, political, cultural, and also emotional stress.

The initial data (end of December 2017) were obtained from official sources. Having constructed the model and estimated the coefficient transits, the results were obtained by solving the system of difference equations and forecasting the amount of subpopulations in each semester for the study period. Hence the model was periodically quantified (6-monthly) from December 2017 to gain an understanding of the population dynamics during the study period. 
Let us start by denoting the subpopulations in semester $\mathrm{n}$ by:

$\mathrm{Z}(\mathrm{n})$ : the zero risk subpopulation is made up of citizens aged over 18 years living in Spain and are idle (live on one's private income); retired citizens with sufficient net pension incomes (more than 1.000 euros/month, and widows/the disabled with fixed incomes (subsidies received from the Government), (Foundation Instituto Edad y Vida, 2016).

These individuals are classified in the $\mathrm{Z}(\mathrm{n})$ subpopulation, and remained in this category for the whole study period.

$\mathrm{PL}(\mathrm{n})$ : the pre-labour category encompasses professional training students and university students (Bachelor and Master students) older than 18 years (Spanish Ministry of Education, Culture and Sports, 2017); PL also includes those who will join the job market after graduating or holding part-time jobs (30\% of the youths population are part-time workers, OECD, 2018a). We apply a Spanish legal principle (Art. 142 and Art. 154 of the Spanish Civil Code, Blasco Gascó, 2018) for belonging to this category. The pre-labour individuals leave this category when they reach the age of 26 years if they did not move to another category in advance.

$\mathrm{E}(\mathrm{n})$ : the entrepreneurs' category. It represents the population of true entrepreneurs, those who start up an economic activity themselves. This concept is the opposite to the false self-employed form, who were forced by the "gig economy" to become self-employed (Spanish Ministry of Labour and Social Security, 2017a)

The fake self-employed growth was boosted by the digitalisation revolution, but has also been one of the consequences of the economic recession period (2007-2016), (Gómez, 2019; OECD, 2018b) as the companies on the capitalist platform may have avoided paying social expenses (General Council of the Judiciary, 2018).

$\mathrm{FNP}(\mathrm{n})$ : this category represents the employees with permanent contracts, including civil servants, public employees and employees of large corporations (banks, successful retail chains and commercial brands). This category also includes half the legalised housekeeping, with a monthly gross amount of incomes above 1.250 euros (International Labor Organization, 2017; Spanish Statistics Institute (INE), 2017).

$\mathrm{P}(\mathrm{n})$ : the precarious population. This subpopulation encompasses the following citizens at the end of the n-nth semester:

- Officially unemployed (INE, 2017).

- Seasonal and/or part-time workers (International Labor Organization, 2017).

- Permanent contracts with gross monthly incomes below 1.250 euros (Spanish Ministry of Labour and Social Security, 2017).

- B economy workers (Business Council for Competitiveness, 2014).

- Pensioners on a minimum state pension (both tax-paying and non-tax-paying forms) (Spanish Ministry of Labour and Social Security, 2017b).

- Half of legalised housekeeping and all non-legalised housekeeping (Spanish Ministry of Labour and Social Security, 2017c).

- False self-employed workers (Spanish Ministry of Labour and Social Security, 2017a). HIM(n): the marginalised subpopulation lacking socio-economic integration, such as gypsies, refugees, undocumented immigrants, convicted prisoners. Since this subpopu- 
lation is not fully documented, it is obtained by subtracting the sum of the other remaining categories from the overall population (Slavkova, 2008; INE, 2017; Foundation Secretariado Gitano, 2018).

By starting with the initial situation at $n=0$ (end of December 2017), the identified subpopulations changed dynamically according to several factors or drivers: economic, legal-occupational (contracts and taxation), technological (digitalisation and automation), political, cultural), demographic (birth, death, immigration and emigration) and psychological (emotional stress). Figure 1 draws the underlying considered factors.

It is not possible to measure accurately all causal factors of transit because causes are not always directly observable (Kemp \& Holmwood, 2003; Olsen \& Morgan, 2005). Thus the quantification of population transits requires several assumptions.

The construction of the model is found in the next hypothesis:

H1: The combination of drivers means that subpopulations shift from one category to another (Damassio, 2018).

$\mathrm{H} 2$ : Subpopulation transits can occur to higher, but also to lower, risk categories, (except $\mathrm{Z}$ ). Once people retire, they will not move from this category; moreover, the idle class will remain at $Z$ for the study period (Wilkinson, 2005).

H3: Individual behaviour is not predictable, but the aggregated type might be (Christakis \& Fowler, 2009; Girard, 2008; Raafat et al., 2009).

H4: Pre-labour individuals leave PL when they reach the age of 26 years (Blasco Gascó, 2018).

Figure 2 represents the dynamic transit among subpopulations from semester $\mathrm{n}$ to semester $n+1$. The transit coefficients are built according to the behavioural hypotheses explaining movements among subpopulations during each semester.

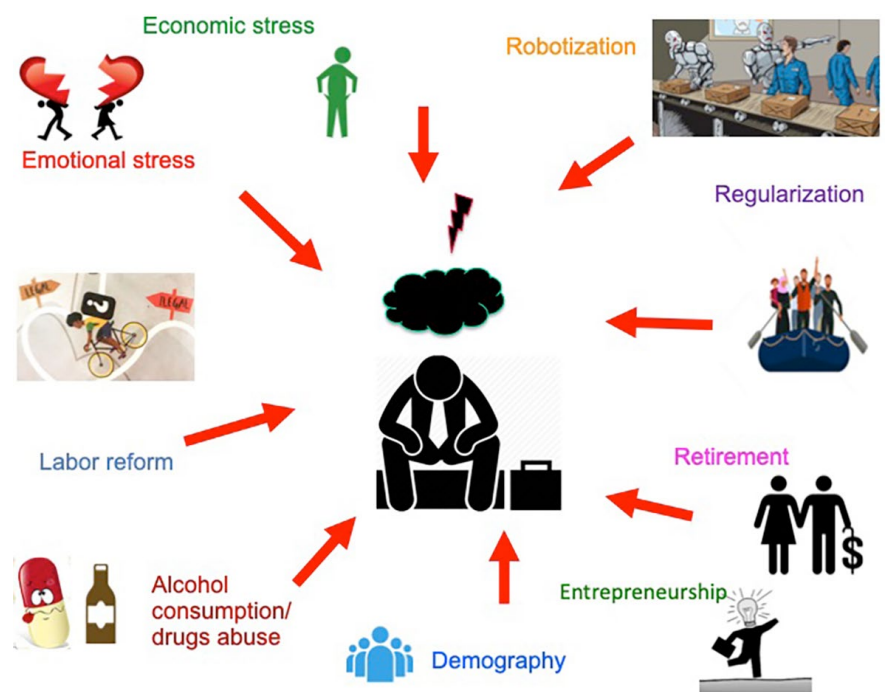

Figure 1. Main drivers of precarity

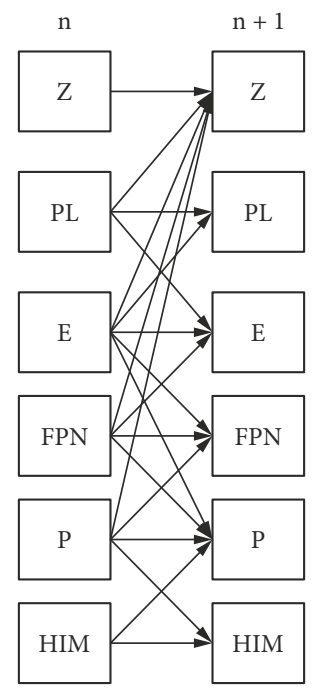

Figure 2. Dynamic transits among subpopulations 
The block diagram drawn in Figure 2 shows that the subpopulations at semester $n+1$ were obtained directly from the known values of the subpopulations at semester $\mathrm{n}$ using the transit coefficients (see mathematical expression 11 on page 12). Thus after computing the initial values at semester $\mathrm{n}=0$, subpopulations were computed iteratively at semester $\mathrm{n}$-th. Each arrow in Figure 2 represents a transit coefficient among subpopulations and semester. These are listed in Table 1 and are explained as follows:

Table 1. Transit coefficients

\begin{tabular}{|r|l|}
\hline$b_{d i}$ & Demographic transits \\
\hline$\alpha_{r i}$ & Retirement transit \\
\hline$\beta_{e i}$ & Economy transit \\
\hline$\beta_{e n i}$ & Entrepreneurship transit \\
\hline$\beta_{r b i}$ & Automation and digitalisation transit \\
\hline$\beta_{r g b i}$ & Regularisation transit \\
\hline$\beta_{a i}$ & Adulthood transit \\
\hline$b_{r l i}$ & Labour reform \\
\hline where $i:$ Z, PL, E, FNP, P, HIM. \\
\hline
\end{tabular}

Starting with the demographic transit, it consists of the net balance between the model's incomers and outgoers. Arrival in the system is explained by those who reach the age of 18 years, but also by those who arrive in Spain to seek a better standard of living. In contrast, individuals leave the system for two reasons: when they die, but also when they emigrate from Spain. The net population transiting due to demographic factors is estimated by considering four variables: birth rate, death rate, immigration and emigration in Spain.

The individuals enter the model when they reach the age of 18 years, and are distributed into three categories: PL, P and HIM.

The number of individuals who reach the age of 18 years in 2017 was 220,315 each semester (INE, 2017).

Most of them entered the model as the PL population: 217,040 (per semester), but a small proportion (2,175; per semester) did so as P (International Labor Organization, 2017, 2016) and 1,100 as HIM (not defined).

In net emigration population terms 44,563 documented individuals arrived in Spain in 2017 (Real Instituto Elcano, 2018; Sociological Research Center, 2018; INE, 2018). This estimation results from the individuals arriving as $\mathrm{P}$ and HIM, but also from those leaving as PL. A small proportion also entered the model by joining categories E, Z, and F (see Table 2).

Table 2. Net balance demographic transit by subpopulation

\begin{tabular}{|c|}
\hline $93.42 \%$ income as $\mathrm{P}$ \\
\hline $8.24 \%$ income as $\mathrm{F}$ \\
\hline $8.24 \%$ income as $\mathrm{E}$ \\
\hline $8.24 \%$ Retired population living in Spain, with income as Z \\
\hline$-38.15 \%$ leave as PL \\
\hline $20 \%$ to HIM \\
\hline
\end{tabular}


In addition, according to the Spanish Home Ministry (Dec. 2017) 13,905 people arrived in Spain seeking refugee status per semester in 2017. They entered the model as the HIM category.

The individuals leaving the model amounted to 205,305 people, who passed away each semester in 2017 (INE).

These deaths were classified by age:

- The individuals who died in the age group $(18,25)$ were removed from PL,

- The individuals aged over 65 years (175,832 each semester) retired in 2017. Their distribution among subpopulations was performed according to the proportion of retired population in $\mathrm{Z}(0)$ and $\mathrm{P}(0)$ over the overall study population.

All the other deaths were distributed among E, F, P and HIM according to the initial amount of each subpopulation at $\mathrm{n}=0$.

The demographic transit was assumed constant for the study period (2017-2021). Following the demographic vector, it is expressed and computed as:

$$
\begin{aligned}
& b_{d i}=\left[\begin{array}{lllll}
b_{d Z} & b_{d P L} b_{d E} & b_{d F N P} & b_{d P} & b_{d H I M}
\end{array}\right]^{T} \text {; } \\
& b_{d i}=[-148,454,196,266,1,248,-6,923,8,761,23,243]^{T} \text {. }
\end{aligned}
$$

The next transit coefficient was retirement, $\left(\alpha_{r i}\right)$. The E(n) and FNP(n) individuals transited to $Z(n+1)$ when they retired and obtained convenient pension incomes. However, $85 \%$ of the individuals in $\mathrm{E}(\mathrm{n})$ and $100 \% \mathrm{P}(\mathrm{n})$ transited to $\mathrm{P}(\mathrm{n}+1)$ when they retired. The former became precarious due to their low-level payments to the SSS towards their pensions, which resulted in low retirement incomes. The latter transited from an unemployment status or holding precarious jobs to precarious retired people, and remained in category $\mathrm{P}$.

The next transit coefficient is explained by the economy $\left(\beta_{e i}\right)$; according to the International Monetary Fund and FUNCAS forecasts: economic growth will create 100.000 new jobs each semester during the study period (Table 3 ).

The population reaching the age of 26 years left the PL category if they had not already done so; $88.2 \%$ of the $\mathrm{PL}(\mathrm{n})$ individuals' transited to $\mathrm{P}(\mathrm{n}+1)$ due to the economic effect $\left(\beta_{e i}\right)$, but also a small proportion of $\mathrm{PL}(\mathrm{n})(11.2 \%)$ obtained a permanent work contract (paid more than 1.250 euros) to become FNP $(n+1)$.

In addition, a small portion of $\mathrm{P}(\mathrm{n})$ improved their labour conditions and became FNP at $\mathrm{n}+1$. Thus the number of PL individuals that transited to FNP at $\mathrm{n}+1$ amounted to 24,876 per semester, and the amount of people who transited from $\mathrm{P}$ to FNP at $\mathrm{n}+1$ came to 27,627 individuals per semester.

This transit was assumed constant for the study period $(2017,2021)$ due to the high high Spanish unemployment level (International Monetary Fund, 2018; Funcas, 2018).

Linked to the economy we find start-ups and other companies that explain the entrepreneurship transit that generated a shift from $\mathrm{PL}(\mathrm{n})$ and $\mathrm{P}(\mathrm{n})$ to $\mathrm{E}(\mathrm{n}+1)\left(\beta_{\text {eni }}\right)$.

Table 4 shows the new entrepreneur jobs for the 2015-2017 period. Here can see that the number of entrepreneurs increases by $1 \%$ annually, ( $0.5 \%$ per semester), according to the Spanish Chamber of Commerce (2018) (Table 4). This transit was assumed constant for the study period (2017-2021) because of the economy's expected behaviour during the short study period. 
Table 3. Forecast of the new contracts for 2019-2021 per semester in Spain (source: Funcas and IMF)

\begin{tabular}{|c|c|}
\hline Year & N new contracts \\
\hline 2019 & 100,000 \\
\hline 2020 & 95,000 \\
\hline 2021 & 90,000 \\
\hline
\end{tabular}

Table 4. Entrepreneur jobs (source: Spanish Chamber of Commerce)

\begin{tabular}{|c|c|}
\hline Year & New entrepreneur jobs \\
\hline 2015 & $1,582,906$ \\
\hline 2016 & $1,597,405$ \\
\hline 2017 & $1,602,339$ \\
\hline
\end{tabular}

Another relevant factor that impacts individuals' risk of precarity lies in the changes brought about by the technological revolution arriving (Rifkin, 2011). In the present-day (21st century), the digitalisation and automation as part of the economy initially destroy repetitive jobs, but slowly generate new technology-related ones (by developing technology or thanks to the outcome of technology). Thus the automation effect is two-fold: it destroys jobs, so $\mathrm{FNP}(\mathrm{n})$ transited to $\mathrm{P}(\mathrm{n}+1)$ (Hawksworth et al., 2018), but also fosters the creation of qualified jobs, and promoted the transit from $\operatorname{PL}(n)$ to $\operatorname{FNP}(n+1)$.

In the early stages of the automation process, many job posts are destroyed; it is estimated that such destruction will be $3 \%$ annual and will reach $21 \%$ by 2025 . In Spain, 120,000 jobs have been destroyed by the digitalisation process only in the banking sector (Sánchez-Silva, 2019). Thus in the long run, it will lead to jobs of a double nature being generated: precarious ones in all sectors (currently the creation of precarious jobs in the logistic and retail sectors is taking place, including the delivery of fast food, but also of merchandise goods) and highly skilled jobs in a minor proportion (ICT (Information and Computer Technologies) sector) (Pesole, Urzí Brancati, Fernández-Macías, Biagi, \& González Vázquez, 2018; Sánchez-Silva, 2019).

It was assumed that such destruction increased from $0.5 \%$ (2018) to $1.3 \%$ (2021) per semester. Our hypothesis relied on the transit of one person from $\operatorname{PL}(n)$ to $\operatorname{FNP}(n+1)$ for every 100 people who transited from $\mathrm{FNP}(\mathrm{n})$ to $\mathrm{P}(\mathrm{n}+1)$ per semester (Esteve, 2018; Ramió, 2018; Opinno, 2018).

The next factor was the legal labour reform, which consisted in a rise in minimum wages per month to reach 1.000 euros by the Government. As a result, part of permanent contracts (assumed to be $\mathrm{P}(\mathrm{n})$ individuals) would transit to $\mathrm{FNP}(\mathrm{n}+1),\left(\alpha_{r l}\right)$ (Blázquez, 2018; Loren, 2018).

This study dealt with the transit from the legal regularisation of immigrants. According to the Spanish Ministry of Labour, every semester 30,000 individuals regularised their occupational status by transiting from $\operatorname{HIM}(\mathrm{n})$ to $\mathrm{P}(\mathrm{n}+1),\left(\beta_{r g b i}\right)$ (Spanish Ministry of Labour and Social Security, 2017c).

Next comes the adulthood transit $\left(\beta_{a i}\right)$, which explained the PL(n) individuals transiting to the other categories when they reached the age of 26 years. In Spain a person becomes independent according to law when they reaches this age, which implies that these individuals are not legally considered family members.

It was assumed that $90 \% \mathrm{PL}(\mathrm{n})$ who reached the age of 26 years transited and became precarious at $(n+1)$ per semester. This percentage was explained by the youth unemployment rate (40\%) in combination with temporality and no set employment, but also by short-term contracts. However, $5 \%$ of $\mathrm{PL}(\mathrm{n})$ transited to $\mathrm{FNP}(n+1)$, while the other $5 \%$ transited to $\mathrm{E}$ per semester $(n+1)$. 
Finally, individuals' emotional status negatively impacts their precariousness; thus $\mathrm{P}(\mathrm{n})$ individuals' transited to HIM $(n+1)$. This transit was modelled by the combination of three factors: long-term unemployed with emotional stress and abuse of drugs and alcohol; 635,500 people within the age interval $(18,65)$ were long-term unemployed in Spain in Dec 2017; of those, $82 \%$ formed part of a long-term relationship, and the probability of breaking up was $50 \%$; $5 \%$ of this population abused drugs and alcohol. As a result, 6,514 people transited from $\mathrm{P}(\mathrm{n})$ to HIM $(\mathrm{n}+1)$ every semester (Spanish Ministry of Health, 2015; INE, 2015).

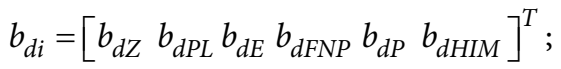

$$
\begin{aligned}
& b_{d i}=[-148,454,196,266,1,248,-6,923,8,761,23,243]^{T} \text {; } \\
& b_{r f i}(n)=\left[\begin{array}{llllll}
b_{r f Z} & b_{r f P L} & b_{r f E} & b_{r f F N P} & b_{r f P} & b_{r f H I M}
\end{array}\right]^{T} \text {; } \\
& b_{r f i}(n)=\left\{\begin{array}{cc}
{[0,0,0,0,486,437,-486,437]^{T},} & 5 \leq n \leq 8 \\
0, & 1 \leq n \leq 4
\end{array} ;\right. \\
& W(n)=[Z(n), P L(n), E(n), \operatorname{FNP}(n), P(n), \operatorname{HIM}(n)]^{T} \text {; } \\
& W(0)=[7,473,115 ; 1,869,121 ; 3,231,279 ; 12,096,000 ; 14,938,735 ; 1,922,065]^{T} \text {; } \\
& W(n+1)=A(n) W(n)+b_{d i}+b_{r l i}(n),
\end{aligned}
$$

where

and

$$
A(n)=\left(a_{i j}(n)\right) 1 \leq i, j \leq 6
$$

$$
\begin{aligned}
& a_{11}=1 ; \\
& a_{13}=\alpha_{r E} ; \\
& a_{14}=\alpha_{r F N P} ; \\
& a_{22}=1-\left(\beta_{e n E}+\beta_{e P}+\beta_{e F N P}+\beta_{a E}+\beta_{a F N P}+\beta_{a P}+\beta_{r b F N P}\right) ; \\
& a_{32}=\beta_{e n E}+\beta_{a E} ; \\
& a_{33}=1-\left(\alpha_{r E}+\alpha_{r P}\right) ; \\
& a_{35}=\beta_{e n E} ; \\
& a_{42}=\beta_{e F N P}+\beta_{a F N P}+\beta_{r b F N P} ; \\
& a_{44}=1-\left(\beta_{r b F N P}+\alpha_{r F N P}\right) ; \\
& a_{52}=a_{52}(n)=\beta_{a P}(n)+\beta_{a E}+\beta_{a F N P} ; \\
& a_{54}=\beta_{r b F N P} ; \\
& a_{55}=a_{55}(n)=1-\left(\alpha_{r l F N P}(n)+\alpha_{e m H I M}+\beta_{e n E}\right) ; \\
& a_{56}=\beta_{r g b H I M} ; \\
& a_{65}=\alpha_{e m H I M} ; \\
& a_{66}=1-\beta_{r g b H I M},
\end{aligned}
$$

and $a_{i j}=0$ for elsewhere. Below the compartment dynamic model is expressed to quantify the precarious population: 


$$
\begin{aligned}
& Z(n+1)-Z(n)=\alpha_{r E}(n) \cdot E(n)+\alpha_{r F N P}(n) \cdot F N P(n)+b_{d Z}+b_{r l Z}(n) ; \\
& P L(n+1)-P L=-\left(\beta_{e n E}(n)+\beta_{e P}(n)+\beta_{e F N P}(n)+\beta_{a E}+\beta_{a F N P}+\beta_{a P}+\right. \\
& \left.\beta_{r b F N P}(n)\right) \cdot P L(n)+b_{d P L}+b_{r l P L}(n) ; \\
& E(n+1)-E(n)=-\left(\alpha_{r E}(n)+\alpha_{r P}(n)\right) \cdot E(n)+\beta_{e n E}(n) \cdot P(n)+ \\
& \left(\beta_{e n E}(n)+\beta_{a E}\right) \cdot P L(N)+b_{d P L}+b_{r l E}(n) ; \\
& F N P(n+1)-F N P(n)=-\left(\beta_{r b F N P}(n)+\alpha_{r F N P}(n)\right) \cdot F N P(n)+ \\
& \left(\beta_{e F N P}(n)+\beta_{a F N P}+\beta_{r b F N P}\right) \cdot P L(n)+b_{d F N P}+b_{r l F N P}(n) ; \\
& P(n+1)-P(n)=\beta_{r b F N P}(n) \cdot F N P(n)+\alpha_{r P}(n) \cdot E(n)+ \\
& \left(\beta_{a P}(n)+\beta_{a E}+\beta_{a F N P}\right) \cdot P L(N)+\beta_{r g b H I M}(n) \cdot H I M(n)- \\
& \left(\alpha_{r l F N P}(n)+\alpha_{e m H I M}+\beta_{e n E}(n)\right) \cdot P(n)+b_{d P}+b_{r l P}(n) ; \\
& H I M(n+1)-H I M=-\beta_{r g b H I M}(n) \cdot H I M(n)+\alpha_{e m H I M}(n) \cdot P(n)+b_{d H I M}+b_{r l H I M}(n) .
\end{aligned}
$$

Compact expression (9) of the model shows that the amount of each subpopulation at semester $\mathrm{n}+1$ is obtained directly from the value of the subpopulations at semester $\mathrm{n}$ once the transit coefficients had been quantified, while expression (11) details the change of each subpopulation in a component-wise manner.

\section{Results}

By computing the model, the subpopulation values per semester were estimated. Table 5 offers the results for the study period starting at the beginning of the study, $n=0$ (December 2017) and ending at $\mathrm{n}=8$ (December 2018).

The results revealed how the precarious subpopulation grew for the 4-year study period, which came close to representing $40 \%$ of the Spanish population in 2021 (Table 6). Conversely to economic recovery, the precarious population increase over time. In contrast, the pre-labour category decreased.

Table 5. Results of subpopulations

\begin{tabular}{|c|c|c|c|c|c|c|c|}
\hline & Semester & Z & PL & E & FNP & P & HIM \\
\hline Dec 2017 & 0 & $7,473,115$ & $1,869,121$ & $3,231,279$ & $12,096,000$ & $14,938,735$ & $1,922,065$ \\
\hline Jun 2018 & 1 & $7,449,712$ & $1,788,686$ & $3,258,738$ & $11,913,190$ & $15,286,054$ & $1,921,821$ \\
\hline Dec 2018 & 2 & $7,427,404$ & $1,708,331$ & $3,286,177$ & $11,747,166$ & $15,631,655$ & $1,921,577$ \\
\hline Jun 2019 & 3 & $7,406,206$ & $1,628,380$ & $3,313,596$ & $11,519,689$ & $16,035,766$ & $1,921,333$ \\
\hline Dec 2019 & 4 & $7,386,134$ & $1,548,549$ & $3,340,996$ & $11,293,735$ & $16,436,577$ & $1,921,089$ \\
\hline Jun 2020 & 5 & $7,367,205$ & $1,469,248$ & $3,368,375$ & $11,496,734$ & $16,405,462$ & $1,920,845$ \\
\hline Dec 2020 & 6 & $7,349,434$ & $1,390,106$ & $3,395,734$ & $11,693,758$ & $16,378,524$ & $1,920,601$ \\
\hline Jun 2021 & 7 & $7,332,841$ & $1,311,611$ & $3,423,072$ & $11,823,943$ & $16,415,429$ & $1,920,357$ \\
\hline Dec 2021 & 8 & $7,317,440$ & $1,233,312$ & $3,450,388$ & $11,948,933$ & $16,455,709$ & $1,920,113$ \\
\hline
\end{tabular}


Table 6. Subpopulations forecast at $\mathrm{n}=0$ and $\mathrm{n}=8$

\begin{tabular}{|l|c|c|c|c|c|c|c|}
\hline & Semester & Z & PL & E & FNP & P & HIM \\
\hline Dec 2017 & 0 & $17.99 \%$ & $4.50 \%$ & $7.78 \%$ & $29.13 \%$ & $35.97 \%$ & $4.63 \%$ \\
\hline Dec 2021 & 8 & $17.29 \%$ & $2.91 \%$ & $8.15 \%$ & $28.23 \%$ & $38.88 \%$ & $4.54 \%$ \\
\hline
\end{tabular}

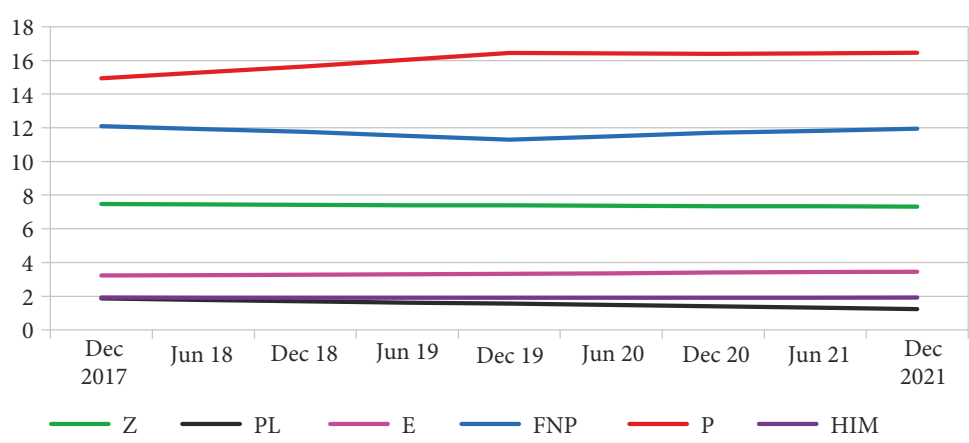

Figure 3. Trend analysis of subpopulations (expressed in millions)

The largest subpopulation during the whole study period was made up of precarious people. As Figure 3 shows, subpopulations P and FNP followed inverse trends, which was explained by the labour reform passed by the Spanish Government in 2018 (Spanish Royal Decree 28/2018, 2018), which came into force in January 2019. Figure 3 represents the trend of each subpopulation for the study period.

The results imply a growing impoverished population ( $\mathrm{P}$ subpopulation increases by about 3\%), whose incomes and quality of life deteriorates at the same rate as their consumption. Consequently, tax revenues lower, and employment is also affected negatively for the slowing down of consumption. In addition, housing affordability (Bentley et al., 2019) becomes an issue as precariousness makes it impossible for people to access mortgages, with an impact on the rise of prices in rented housing markets (Pellicer, 2017).

One long-term implication of precariousness is that the Spanish pension system based on workers' tax payments is not sustainable. Not only does precariousness reduce funding for current pensions, but it also forecasts a generation of low pensioners unable to cover their own living expenses. Table 5 shows how the pre-labour population is reduced by about $1.5 \%$. The explanation for this trend is the constantly low Spanish birth rate, combined with the Spanish qualified youths emigrating to seek better wages.

\subsection{Simulation of scenarios}

\subsubsection{Sensitivity analysis of the impact of automation/digitalisation}

Lack of certainty of the impact of the automation/digitalisation process on the labour market allowed its effects on the study subpopulations to be simulated. This showed that the automation/digitalisation effect could evolve from the baseline, considered to be up to 4 -fold higher (Dedios-Pleite, 2019). 
The results of this simulation for the populations at the end of the study period $(n=8$, December 2021) are graphically represented below. The most affected populations were $P$ and FNP. As Figure 4 shows, for each 1\% increase in the impact of the automation/digitalisation on the labour market, the FNP population drops $10 \%$ and the $\mathrm{P}$ subpopulation grows by about $6 \%$.

\subsubsection{Sensitivity analysis of companies' incentive to increase their employees' wages.}

A fiscal measure was simulated to mitigate precarious population growth based on companies' incentive to distribute a portion of their economic profits through their employees' wages. As a result, employees' wages would increase up to 1.250 euros/moth. This measure would imply an increase in wages, but not a labour reform. The incentive would be based on tax cuts for those companies that increase their employee's economic payments. Otherwise, the companies that do not follow this measure would be fiscally punished.

This measure was assumed to be adopted at the end of the study period (December 2021, $\mathrm{n}=8)$. The affected subpopulation was $\mathrm{P}(\mathrm{n}=8)$, with permanent job contracts, which would transit to FNP $(n=9)$ thanks to their improved economic conditions.

Figure 5 reflects the results of the model for the two affected subpopulations (FNP and $\mathrm{P}$ populations) and the trend of populations Pm and FNPm once the measure was implemented in $\mathrm{n}=8$ (December 2021). The results show how the $\mathrm{P}$ subpopulation would decrease, while FNP would increase over time due to the fiscal measure implemented (as Pm and FNPm curves show).

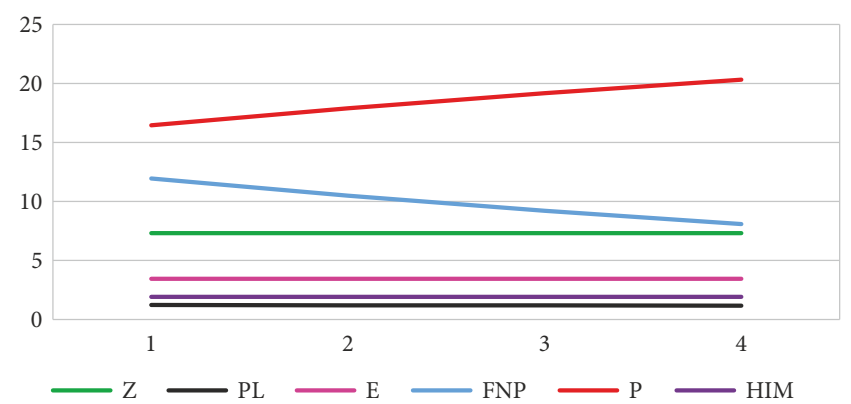

Figure 4. Sensitivity analysis of the impact of automation/digitalisation at $\mathrm{n}=8$ (in millions)

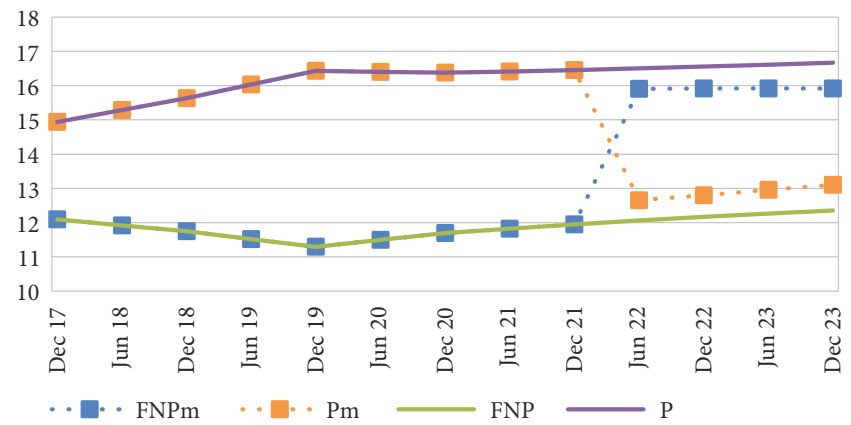

Figure 5. Sensitivity analysis of the impact of the fiscal measure with the labour impact during the study period (in millions) 
Thus the middle class would grow by about $4 \%$, as Figure 5 shows. However, if this measure were taken in an isolated manner, the precarity problem would only partially improve. The beneficiaries of this measure will only be the affected permanent employees. However, it is necessary to carry out a labour reform to reduce part-time contracts and seasonality to break down the rise in the precariat in Spain.

\section{Conclusions}

This study shows a deterioration in the Spanish population's living standards despite the improvement in macroindicators given the destruction of the Spanish middle class and an impoverished society. One of the consequences of the precarity problem is worse well-being of individuals, increased health expenditure and low birth rates. In addition, precarity is linked to lack of affordable housing and a change in the behavior pattern from purchasing to renting (Fuster, Arundel, \& Susino, 2019).

Stopping to this social problem would require policymakers' actions to provide incentives as permanent contracts with suitable economic payment, but also new formulas to link employees' wages to the firm's performance (Todolí Signes, 2016).

This work contributes to previous knowledge by modelling the population at risk of precariousness in Spain for a short time period (2017-2021).

The model allowed alternative scenarios to be simulated according to the varying underlying hypotheses.

One of the potential utilities of this model is that it quantifies the magnitude of the main social problem experienced in Spain: the Precariat. It also allows forecasts that the impact of alternative actions would have in order to mitigate its rise.

The simulations performed herein allowed one conclusion to be drawn: uncomplicated paths exist to help mitigate the increase in precariousness in Spain. Specific actions were identified and quantified to be implemented nationwide instead of providing ambiguous or unintelligible arguments about how to solve the problem (Lapuente, 2015).

In Spain, wages have traditionally been set, compared to other countries like England, Poland, Slovenia, Finland or France (Todolí Signes, 2017b), where Governments encourage the use of wage systems linked to business results, and where inequality of wages is significantly lower than in Spain. France is the only EU country that legally requires companies with more than 50 workers to distribute profits among workers. In a more international environment, such as Chile or the State of Oregon (USA), the distance between the lowest and highest salary in a company is limited to a multiple of 10 . In any case, taking labour and economic-fiscal measures should go hand in hand with the legislator, and must always aim to reduce wage inequality or contract types, and should encourage labour productivity. In order to mitigate precariousness, several measures are propose to be adopted, such as fiscally punishing those companies that do not distribute a portion of profits among employees; prohibiting working overtime, which also facilitate payments in "black" and fiscal opacity. This technique is usually applied to part-time contracts as a mechanism to avoid permanently contracting workers. Thirdly, the percentage of temporary jobs could be limited and determined in accordance with either the number of workers with a permanent contract or company size (measured by the value of its sales or the number of employees it hires). 
One of the potential advantages of the model is its applicability to other geographical areas using local data. However, its application to other areas requires the careful reworking and adaptation to each region's idiosyncrasies.

The primary limit of this study is related to the nature of the model. Thus to favour the reliability of the hypotheses on economic behaviour, demographic changes, the legal framework and the time period should be short. This would mean that a long-term period would be applicable, but the model's robustness would weaken.

Future research should consist in modelling some specific labour reforms to be applied by the Spanish Government and to assess their impact on the precariat problem. Specifically, the study will analyse the impact of the legal limit of part-time contracts on precarity, but also on the general Spanish economy. Interest lies in assessing the effect of this measure on different stakeholders' behavioural reaction (employees, employers and the police-makers). The challenge of future research involves measuring the impact of the considered new regulations, but also controlling other potential influences that could overlap these (e.g. international Trade fights, the potential growth of the price of a barrel of oil; political instability in Europe).

\section{Author contributions}

EDLP and LJ conceived the study, EDLP, LJ and ATS were responsible for the design and development of the data analysis. EDLP, LJ and PM were responsible for data collection and analysis. EDLP and LJ were responsible for data interpretation. EDLP and LJ wrote the first draft of the article, ATS and PM reviewed the first draft.

\section{Disclosure statement}

Authors declare not having any competing financial, professional, or personal interests from other parties.

\section{References}

Acemoglu, D., \& Autor, D. (2011). Skills, tasks and technologies: Implications for employment and earnings. In Handbook of labor economics (Vol. 4, pp. 1043-1171). https://doi.org/10.1016/S0169-7218(11)02410-5

Andrés, R. (2018, June 12). La otra dramática cara del 'boom’ del alquiler: mayores con pensiones bajas. La Vanguardia. Retrieved from https://www.lavanguardia.com/local/valencia/20180612/ 444152184736/boom-alquileres-personas-mayores-pensiones-bajas-hogares-compartidos-valencia. html (in Spanish)

Arntz, M., Gregory, T., \& Zierahn, U. (2016). The risk of automation for jobs in OECD countries: A comparative analysis (Working papers No. 189). OECD Publishing, Paris. https://doi.org/10.1787/5jlz9h56dvq7-en

Barbieri, P. (2009). Flexible employment and inequality in Europe. European Sociological Review, 25(6), 621-628. https://doi.org/10.1093/esr/jcp020

Bentley, R., Baker, E., \& Aitken, Z. (2019). The 'double precarity' of employment insecurity and unaffordable housing and its impact on mental health. Social Science \& Medicine, 225, 9-16.

https://doi.org/10.1016/j.socscimed.2019.02.008 
Bericat, E., \& Cascales-Mira, M. (2019). Job quality. In E. Bericat, \& M. L. Jiménez-Rodrigo (Eds.), The quality of European societies (Vol. 75). Cham: Springer. https://doi.org/10.1007/978-3-030-05023-8

Blasco Gascó, F. (2018). Código civil: 22a edición 2018 anotada y concordada. Valencia (in Spanish).

Blázquez, P. (2018, June 28). ¿Por qué España puede permitirse subir por fin los salarios? La Vanguardia. Retrieved from https://www.lavanguardia.com/economia/20180628/45445735936/salariosempleo-productividad.html (in Spanish).

Brady, D., \& Biegert, T. (2017). The rise of precarious employment in Germany. In A. L. Kalleberg, \& S. P. Vallas (Eds.), Precarious work (Vol. 31, pp. 245-271). Emerald Publishing Limited. https://doi.org/10.1108/S0277-283320170000031008

Business Council for Competitiveness. (2014). España 2018. Retrieved from http://www.spainfinancialcentre.com/sites/default/files/20141103_informe_espana_2018.pdf (in Spanish).

Č́belková, I. (2015). The effect of social transfers on the level of unemployment of disabled in EU countries. Economics \& Sociology, 8(1), 298-307. https://doi.org/10.14254/2071-789x.2015/8-1/23

Christakis, N. A., \& Fowler, J. H. (2009). Connected: the surprising power of our social networks and how they shape our lives. Boston, Massachussets, USA: Little Brown and Company.

Charlwood, A., Forde, C., Grugulis, I., Hardy, K., Kirkpatrick, I., MacKenzie, R., \& Stuart, M. (2014). Clear, rigorous and relevant: publishing quantitative research articles in Work, employment and society, Work, Employment and Society, 28(2), 155-167. https://doi.org/10.1177\%2F0950017014526448

Clarke, J., \& Newman, J. (2012). The alchemy of austerity. Critical Social Policy, 32, 299-319. https://doi.org/10.1177\%2F0261018312444405

Costas, A. (2018, September 9). Por qué los muy ricos progresan y los demás no. El País. Retrieved from https://elpais.com/economia/2018/09/07/actualidad/1536333591_827747.html (in Spanish)

Damasio, A. (2018). The strange order of things: life, feelings, and the making of cultures. Barcelona, Spain: Planeta (in Spanish).

Dedios-Pleite, P. (2019, February 11). Es un mito pensar que la robotización va a sustituir puestos de trabajo. La Vanguardia. Retrieved from https://www.lavanguardia.com/economia/innovacion/20190210/46294662888/pascual-dedios-pleite-mito-robotizacion-sustituir-trabajo.html (in Spanish)

De la Poza, E., \& Jódar, L. (2018). A short-term population model of the suicide risk: the case of Spain. Culture, Medicine, and Psychiatry, 42(4), 800-820. https://doi.org/10.1007/s11013-018-9589-4

De la Poza, E., Jódar, L., \& Pricop, A. (2017). Modelling and analysing voting behaviour: the case of the Spanish general elections. Applied Economics, 49(13), 1287-1297.

https://doi.org/10.1080/00036846.2016.1217307

Doogan, K. (2009). New capitalism? The transformation of work. Cambridge, UK: Polity Press.

Drahokoupil, J., \& Fabo, B. (2016). The platform economy and the disruption of the employment relationship (ETUI policy brief No. 5/2016). Brussels. https://doi.org/10.2139/ssrn.2809517

Dudek, H., \& Lisicka, I. (2013). Determinants of poverty-binary logit model with interaction terms approach. Ekonometria, 3(41), 65-77.

Esteve, F. (2018). La amenaza de la robotización del empleo en España. Retrieved from http://www. forumlibertas.com/la-amenaza-de-la-robotizacion-del-empleo-en-espana/ (in Spanish)

Eurostat. (2018). Involuntary part-time employment as percentage of the total part-time employment for young people by sex and age. Retrieved from https://ec.europa.eu/eurostat/en/web/productsdatasets/-/YTH_EMPL_080

Eurostat. (2016). Income Inequality in the EU. Retrieved from http://ec.europa.eu/eurostat/web/products-eurostat-news/-/EDN-20180426-1 
Felgueroso, F., Millán, A., \& Torres, M. (2018). Población especialmente vulnerable ante el empleo en España. Cuantificación y caracterización. Estudios sobre la Economía Española, 2017. FEDEA, Madrid. Retrieved from http://documentos.fedea.net/pubs/eee/eee2017-07.pdf (in Spanish)

Fischhoff, B., \& Kadvany, J. (2011). Risk: A very short introduction. Oxford: Oxford University Press. https://doi.org/10.1093/actrade/9780199576203.001.0001

Foundation Secretariado Gitano. (2018). Retrieved from https://www.gitanos.org/que-hacemos/areas/ empleo_y_formacion_profesional/en_cifras.html

Foundation Instituto Edad y Vida. (2016). La revolución de la longevidad y su influencia en las necesidades de financiación de los mayores. Retrieved from https://www.edad-vida.org/publicaciones/larevolucion-de-la-longevidad-y-su-influencia-en-las-necesidades-de-financiacion-de-los-mayores/ (in Spanish)

Funcas. (2018). Previsiones económicas para España 2019-2021. Retrieved from https://www.funcas.es/ Indicadores/Indicadores.aspx? Id=1 (in Spanish)

Fuster, N., Arundel, R., \& Susino, J. (2019). From a culture of homeownership to generation rent: housing discourses of young adults in Spain. Journal of Youth Studies, 22(5), 585-603. https://doi.org/10.1080/13676261.2018.1523540

Galston, W. A. (2018, March 8). Order from chaos. The rise of European populism and the collapse of the center-left. Brookings. Retrieved from https://www.brookings.edu/blog/order-from-chaos/2018/03/08/the-rise-of-european-populism-and-the-collapse-of-the-center-left/

General Council of the Judiciary. (2018, June 1). Judgment of Labor Court $n 6$ of Valencia n244/2018. Retrieved from https://www.isdc.ch/media/1590/13-juzgado-valencia-1-junio.pdf (in Spanish)

Girard, R. (2008). Mimesis and theory: essays on literature and criticism, 1953-2005. Stanford University Press.

Goldthorpe, J. H. (2016). Sociology as a population science. Cambridge: Cambridge University Press. https://doi.org/10.1017/СBO9781316412565

Gómez, M. V. (2019, February 15). Precariedad laboral: La inspección detecta en solo un año casi 19.000 falsos autónomos. El País. Retrieved from https://elpais.com/economia/2019/02/15/actualidad/1550263791_159238.html (in Spanish)

Goos, M. A., Manning, A., \& Salomons, A. (2014). Explaining job polarization: routine-biased technological change and offshoring. The American Economic Review, 104(8), 2509-2526. https://doi.org/10.1257/aer.104.8.2509

Haddad, W. M., Chellaboina, V., \& Nersesov, S. G. (2002). Hybrid nonnegative and compartmental dynamical systems. Mathematical Problems in Engineering, 8(6), 493-515. https://doi.org/10.1080/1024123021000066426

Hawksworth, J., Berriman, R., \& Goel, S. (2018). Will robots really steal our jobs? An international analysis of the potential long-term impact of automation. Retrieved from https://www.pwc.com/hu/ hu/kiadvanyok/assets/pdf/impact_of_automation_on_jobs.pdf

Hornstein, A., Krusell, P., \& Violante, G.L. (2005). The effects of technical change on labour market inequalities. In P. Aghion, \& S. N. Durlauf (Eds.), Handbook of economic growth. Elsevier B.V. https://doi.org/10.1016/S1574-0684(05)01020-8

International Labor Organization. (2017). Talking through the crisis: Social dialogue and industrial relations trends in selected EU countries. Retrieved from https://www.ilo.org/global/publications/books/ WCMS_548950/lang--en/index.htm

International Monetary Fund. (2018). Retrieved from www.imf.com

Kalinowski, S., \& Kiełbasa, B. (2017). Risk of poverty and social exclusion in the European Union in the context of sustainable development. Paper presented at the Proceedings of the $8^{\text {th }}$ international scientific conference rural development 2017, Aleksandras Stulginskis University, Lithuania. https://doi.org/10.15544/RD.2017.044 
Kemp, S., \& Holmwood, J. (2003). Realism, regularity and social explanation. Journal for the Theory of Social Behavior, 33(2), 165-187. https://doi.org/10.1111/1468-5914.00212

Kiersztyn, A. (2017). Non-standard employment and subjective insecurity: how can we capture job precarity using survey data? In A. L. Kalleberg, \& S. P. Vallas (Eds.), Precarious work (Research in the Sociology of Work, Vol. 31). Emerald Publishing Limited. https://doi.org/10.1108/S0277-283320170000031003

Krusell, P. L., Ohanian, E., Rios-Rull, J. V., \& Violante, G. L. (2000). Capital-skill complementarity and inequality: a macroeconomic analysis. Econometrica, 68(5), 1029-1054. https://doi.org/10.1111/1468-0262.00150

Lapuente, V. (2015). El retorno de los chamanes. Peninsula, Barcelona (in Spanish).

León-Castro, E., Merigó, J. M., Avilés-Ochoa, E., Gil-Lafuente, A. M., \& Herrera-Viedma, E. (2019). Modelling and simulation in business, economics and management. Technological and Economic Development of Economy, 25(4), 571-575. https://doi.org/10.3846/tede.2019.9365

Loren, E. (2018, July 23). Sánchez elevará el salario mínimo a 1.000 euros en 2020. Huffington Post. Retrieved from https://www.huffingtonpost.es/2018/07/23/sanchez-elevara-el-salario-minimo-a1-000-euros-en-2020_a_23487907/ (in Spanish)

Martínez García, J. S. (2013). Estructura social y desigualdad en España. Madrid: Los Libros de la Catarata (in Spanish).

Micklethwait, J., \& Wooldridge, A. (2014). The fourth revolution. The global race to reinvent the state. New York: The Penguin Press.

Muñoz de Bustillo Llorente, R., \& Pinto Hernández, F. (2016). Reducing precarious work in Europe through social dialogue: the case of Spain (Report for the European Commission). University of Salamanca. Retrieved from http://www.research.mbs.ac.uk/ewerc/Our-research/Current-projects/ Reducing-Precarious-Work-in-Europe-through-Social (in Spanish).

Nachtwey, O. (2017). La sociedad del descenso. Madrid: Paidos (in Spanish).

OECD. (2018a). Statistics. Labor force Statistics. Retrieved from http://www.oecd-ilibrary.org/employment/oecd-labour-force-statistics_23083387

OECD. (2018b). Preparing for the future of work. Job Creation and Local Economic Development. OECD Publishing, Paris. Retrieved from https://doi.org/10.1787/9789264305342-en

Olsen, W., \& Morgan, J. (2005). A critical epistemology of analytical statistics: addressing the sceptical realist. Journal for the Theory of Social Behavior, 35(3), 255-284. https://doi.org/10.1111/j.1468-5914.2005.00279.x

Opinno. (2018). Informe ADDECO sobre el futuro laboral en España. Retrieved from https://www.ceu. es/joblab/documentacion/informeAdecco.pdf (in Spanish)

Oxfam Intermón. (2018). ¿Realidad o Ficción? La recuperación económica, en manos de una minoría. Retrieved from https://oxfamintermon.s3.amazonaws.com/sites/default/files/documentos/files/ recuperacion-economica-una-minoria.pdf (in Spanish)

Pęciak, R., \& Tusińska, M. (2015). The fight against poverty in the European Union-expectations versus reality. Journal of International Studies, 8(2), 8-2. https://doi.org/10.14254/2071-8330.2015/8-2/10

Pellicer, L. (2017). Spain's new real estate boom: the rental market. El País. Madrid. Retrieved from https://elpais.com/elpais/2017/07/03/inenglish/1499075153_385634.html

Pesole, A., Urzí Brancati, M. C., Fernández-Macías, E., Biagi, F., \& González Vázquez, I. (2018). Platform Workers in Europe. Luxembourg: Publications Office of the European Union.

Pratt, G. A. (2015). Is a Cambrian Explosion coming for robotics? The Journal of Economic Perspectives, 29(3), 51-60. https://doi.org/10.1257/jep.29.3.51

Raafat, R. M., Chater, N., \& Frith, C. (2009). Herding in humans. Trends in Cognitive Sciences, 13(10), 420-428. https://doi.org/10.1016/j.tics.2009.08.002 
Ramió, C. (2018). Cifras sobre el potencial impacto de la robotización en las Administraciones Públicas. Retrieved from https://www.administracionpublica.com/cifras-sobre-el-potencial-impacto-de-larobotizacion-en-las-administraciones-publicas/\# (in Spanish)

Real Instituto Elcano. (2018) Retrieved from http://www.realinstitutoelcano.org/wps/portal/rielcano_ es/contenido?WCM_GLOBAL_CONTEXT=/elcano/elcano_es/zonas_es/demografia+y+poblacion/ ari6-2018-gonzalezenriquez-martinezromera-debilidades-emigracion-espana (in Spanish)

Rifkin, J. (2011). The zero marginal cost society. New York: Palgrave Macmillan.

Rodríguez-Piñero, M., \& Hernández-Bejarano, M. (2017). Economía colaborativa y trabajo de plataforma. Bomarzo, Albacete (in Spanish).

Rubery, J., Grimshaw, D., Keizer, A., \& Johnson, M. (2018). Challenges and contradictions in the 'normalising' of precarious work. Work, Employment and Society, 32(3), 509-5527. https://doi.org/10.1177\%2F0950017017751790

Sánchez-Silva, C. (2019, January 18). Las empresas pisan el acelerador de los ERE. El País. Retrieved from https://elpais.com/economia/2019/01/18/actualidad/1547807569_677451.html (in Spanish)

Sassen, S. (2014). Expulsions: brutality and complexity in the global economy. Harvard University Press. https://doi.org/10.4159/9780674369818

Slavkova, M. (2008, December). Being gypsy in Europe. The case of Bulgarian Roma workers in Spain. Balkanologie, XI, 1-2.

Srnicek, N. (2017). Platform capitalism. Cambridge: Polity Press.

Standing, G. (2012). The precariat. The new dangerous class. London: Bloomsbury.

Sociological Research Center. (2018). Retrieved from http://www.cis.es/cis/opencms/ES/index.html (in Spanish)

Spanish Chamber of Commerce. (2018). Perfil del emprendedor. Retrieved from https://www.camara. es/blog/creacion-de-empresas/perfil-del-emprendedor-espanol (in Spanish)

Spanish National Statistics Institute. (2015). Retrieved from http://www.ine.es

Spanish National Statistics Institute. (2016). Retrieved from http://www.ine.es

Spanish National Statistics Institute. (2017). Retrieved from http://www.ine.es

Spanish National Statistics Institute. (2018). Retrieved from http://www.ine.es

Spanish Ministry of Labour and Social Security. (2017a). Trabajadores autónomos, personas físicas, en alta en la Seguridad Social, resumen de resultados a 31 de diciembre de 2017. Retrieved from http://www. mitramiss.gob.es/es/sec_trabajo/autonomos/economia-soc/autonomos/estadistica/2017/4trim/Publicacion_RESUMEN_DE_RESULTADOS_DICIEMBR_2017.pdf (in Spanish)

Spanish Ministry of Labour and Social Security. (2017b). Pensiones de la Seguridad Social, diciembre 2017. Retrieved from http://www.seg-social.es/wps/portal/wss/internet/EstadisticasPresupuestosEstudios/Estadisticas/EST23/EST24/EST192 (in Spanish)

Spanish Ministry of Labour and Social Security. (2017c). Retrieved from http://www.mitramiss.gob.es/ es/sec_emi/index.htm

Spanish Ministry of Health. (2015). Encuesta sobre alcohol y otras drogas en España, EDADES. Retrieved from http://www.pnsd.msssi.gob.es/profesionales/sistemasInformacion/sistemaInformacion/encuestas_EDADES.htm

Spanish Ministry of Education, Culture and Sports. (2017). Datos y cifras. Curso escolar 2017/2018. Retrieved from http://www.educacionyfp.gob.es/servicios-al-ciudadano-mecd/dms/mecd/serviciosal-ciudadano-mecd/estadisticas/educacion/indicadores-publicaciones-sintesis/datos-cifras/Datosycifras1718esp.pdf (in Spanish) 
Spitz-Oener, A. (2006). Technical change, job tasks, and rising educational demands: looking outside the wage structure. Journal of Labor Economics, 24, 235-270. https://doi.org/10.1086/499972

Symeonaki, M., Parsanoglou, D., \& Stamatopoulou, G. (2019). The evolution of early job insecurity in Europe. SAGE Open, 1-23. https://doi.org/10.1177/2158244019845187

Todolí Signes, A. (2015). El impacto de la "Uber economy" en las relaciones laborales: Los efectos de las plataformas virtuales en el contrato de trabajo. Luslabor, 3, 1-25.

Todolí Signes, A. (2016). Salarios y productividad. Valencia: Tirant lo Blanch.

Todolí Signes, A. (2017a). El trabajo en la era de la economía colaborativa. Valencia: Tirant lo Blanch.

Todolí Signes, A. (2017b). El bonus salarial. Valencia: Tirant lo Blanch.

Wilkinson, R. G. (2005, January). The impact of inequality: how to make sick societies healthier. New York: The New Press. 